\title{
From Tradition to Transformation among Villagers in Sigi Regency (Histo-Sosiological Perspective)
}

\author{
Nuraedah \\ Faculty of Teaching and Education, Tadulako University Palu \\ Central of Sulawesi, Indonesia \\ Corresponding author: nuraedahirwan@yahoo.com
}

Received: May 16, 2013 Accepted: June 24, 2013 Published: August 21, 2013

doi:10.5296/ijssr.v1i1.4159 URL: http://dx.doi.org/10.5296/ijssr.v1i1.4159

\begin{abstract}
The objectives of this study are reveal type of traditional action of villagers in Sigi Regency, to reveal transformational process of traditional people in Sigi Regency, and to disclose the consequence change from tradition to transformation among villagers in Sigi Regency. The research is of qualitative research with histo-sociological approach. Source of data are collected from words and behavior or act observed from informant trough observations and interviews through interaction between writer and local residents, to the trace of documentation about past happenings and facts, about expansion of Dutch colonialism in the land of Sigi, and also from personal documentation possessed by certain clan. The findings show that type of traditional action in Sigi Regency is the realization of of prower and dignity in which the actors are respectively magau, jogugu, galara, pabicara, punggawa, kalula and to tua ada' of the past time and puempanga, bayasa, bule and topodondi in current time. Traditional people of Sigi Regency transform though historical transformation, clan differentiation and community difference in terms of social and economic characteristics. Consequences of change from traditional to transformative based on: a) inter-clan (fam) social cohesion due to the existence of high sentiment as for personal feeling come from the same clan, b) inter-clan social mobility, and c) conflict between older and younger generation. Research findings show that historical process leaves much less room for evolution to establish irrational and rational social arrangement among villagers based on the condition and tradition to transformation they follow. Condition and arrangement they follow is socially and economically measurable in a representative study through historical sociology.
\end{abstract}

Keywords: tradition, villagers, historical sociology 


\section{Introduction}

\subsection{Background}

Process of transformation in Sigi Regency as a process resulted from partial regional expansion is driven by historical forces. Initiated from a tradition as a past time legacy, original tradition Vunja Mpae, type of traditional action to kinship group (clan) having ability to remain exist undergo transformation from traditional elite to modern elite.

Besides having original tradition, Kingdom of Sigi also has artificial tradition which is political tradition. Political tradition with the dimension of strength is taken place in the belief that the king have magic-religious power as a descendant from the sky (upper world) which is "to-manurung", also a belief that power of the king is in "guma", a royal scepter and keris, it is believed by some people that the king has power more than commoners.

Past and recent time power of Lammakarate clan is not only because of the past time glory, but also because of the wide access of spacious land and labor to cultivate the land. Transformation process of traditional people in Sigi Regency was initiated by historical transformation of villagers to regional expansion of Sigi Regency, then followed by transformation due to clan differentiation by educational background. Clan differentiation because of wealth and legacy, and regional strategic also take an important role in transformational process. Finally, difference in characteristic or identity as a reference for transformational process seen from social and economic characteristics view of farming community is a factual prove of transformational process in Sigi Regency.

Literatures in relation with this study are based on the theory by Frans Husken (1998), Lerner (1983), Kurasawa Aiko (1993) and Garna (1993), Sumarjan (1982), Nari (2009) and the writing of Kruyt (1938), while local references are taken from writings by Mahid, Haliadi Sadi and Syafrullah Arisyanto (2002) and writings by Hasan, Nuraedah and Wilman Darsono L. (2006), which discussed slightly about the relationship between Kingdom of Sigi and Kingdom of Tojo Una-Una in kinship bond.

The consideration afore mentioned motivated the writer to choose Sigi Regency as the object of the research for the reason that Sigi Regency has time and space of change that is histo-sociologically traceable as the availability of primary and secondary data source to support the research writing. One of the supporting proves written in the writing by Department of Education and Culture (1996/1997) shows that Sigi has a complete historical reference due to the agreement of consent to the Dutch authority Lange Contract which was forced to be signed by Magau of Sigi and custom board including Kulawi on August 19, 1891. Beside, Sigi and Kulawi are the biggest central area of kingdom in Kaili hill of the time. Data source availability mentioned give a chance to trace and reconstruct the change since Dutch expansion to regional expansion and further establishment of the regency. The research is limited to the discussion of tradition to transformation exist among villagers in Sigi Regency. 


\subsection{Formulation of the Problems}

Referring to above mentioned background, then discussions is presented to answer some problems related to historical sociology as follow:

(1) What is the type of traditional action of villagers in Sigi Regency?

(2) How did traditional people in Sigi Regency transform?

(3) What are the consequences of change from tradition to transformation in Sigi Regency?

\section{Research Method}

The research is of qualitative with historical sociological approach. Research method collects data in the form of observable words and behavior or action from the subject itself. Data were also obtained from documentation of Dutch colony heritage in the land of Sigi. Research location is in Bora village, Sigi Biromaru District, Sigi Regency, Central Sulawesi Province.

Data source search model can be seen in Figure 1.

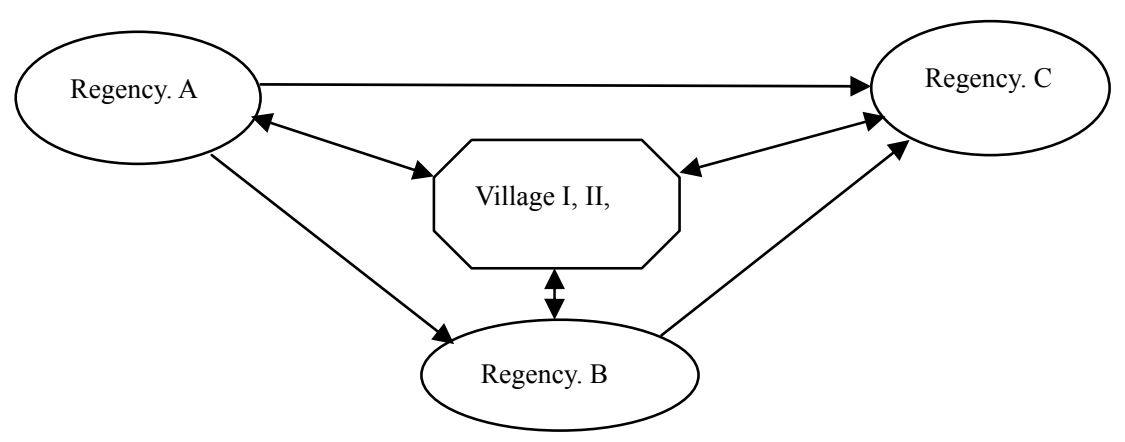

Figure 1. Data source search model

Data collection technique used in this research covers observation, interview, and documentation. Interactive analysis uses three activity workflows performed simultaneously, they are: data reduction, data presentation, and conclusion/verification.

\section{Discussion}

\subsection{Tradition of Villagers of Sigi Regency: The Trace of Past Time Heritage}

\subsubsection{Structure of Traditional People}

Community structure during the leadership of Lamakarate consisted of magau (king), the nobles or royal officials, religious group and kadhi (king advisors). They who have been mentioned above sit in high position in the community, while commoners consists of farmer who have farm land, and farmer who have very few farm land and those who do not have farming land at all. Symbols identical with Lamakarate and his descendants are symbol of charisma, social cohesion and dignity.

Based on the information from Tahwiri Labontina it is known that the owner of the largest land in the region is Lamakarate, from farm land to wide residential land, it is understandable 
as Lamakarate and his descendants experienced of becoming king both in Kingdom of Sigi and Kingdom of Sigi Dolo. In linguistic structure of to tua ngata people of Sigi, for "magau" it is used "tumputta" to address the king which means = our master. Beside the nobles, there also people of proletariant group which they called as "to dea", which means a mass. And gentlemen in the village belong to a separate group which called as to tua ngata means the elderly of the village, the elders, they who has its own special place in the heart of to dea. Each nobleman owns slave which they called as "batua". Batua is to serve the need and interest of magau. In the time of Duct colonialism, magau did not need courier, he only used "tambur", an instrument used by hitting, to know the condition of his people, for example if there is a news about death and so on, so hit the tambur or drum as a sign of the coming distress or offending security and disaster to the mass.

To dea always shows respect toward the nobles, as he also pay respect to their parents. Whenever sit together with a nobleman, it is prohibited to wash the mouth or eat betel leaves before the nobleman. This means it is not allowed to precede every action of noblemen. While a nobleman sit for eating, it is not allowed anyone behind him/her to stand, walk or run. It is also not permitted to use any chore used by noblemen, also any personal belonging, such as: sleeping mat, pillow, pouch to save betel leaves, they are forbidden to be touch by others who are not in the same daily association with him/her. Beside, it is forbidden to sit back before magau, to sit by spearing or hanging legs is considered as impolite. Things mentioned above if violated then will be considered as defiance and insulting.

In regions part of Kingdom of Sigi Dolo, chieftain and "magau" are selected from a group of noblemen. The people of the village highly depend on the chieftain who is a nobleman. Upon arriving in Central Sulawesi, so we will frequently heard name of Kulawi, a big kingdom of its time. Based on Yore Pamei it is informed that before the Duct colonialism, king is entitled "magau", but after the Dutch coming, the title for a leader of a kingdom is "king". The first king to lead Kulawi Kingdom is Hangkelea, the administration system was still referred to the tradition. After the death of Hangkelea, the governance was continued by his brother Tovualangi. Tovualangi then took control the governance which then fighted against Dutch colonialism. Below are ngatas under the authority of Kulawi Kingdom during the governance of Magau Tovualangi.

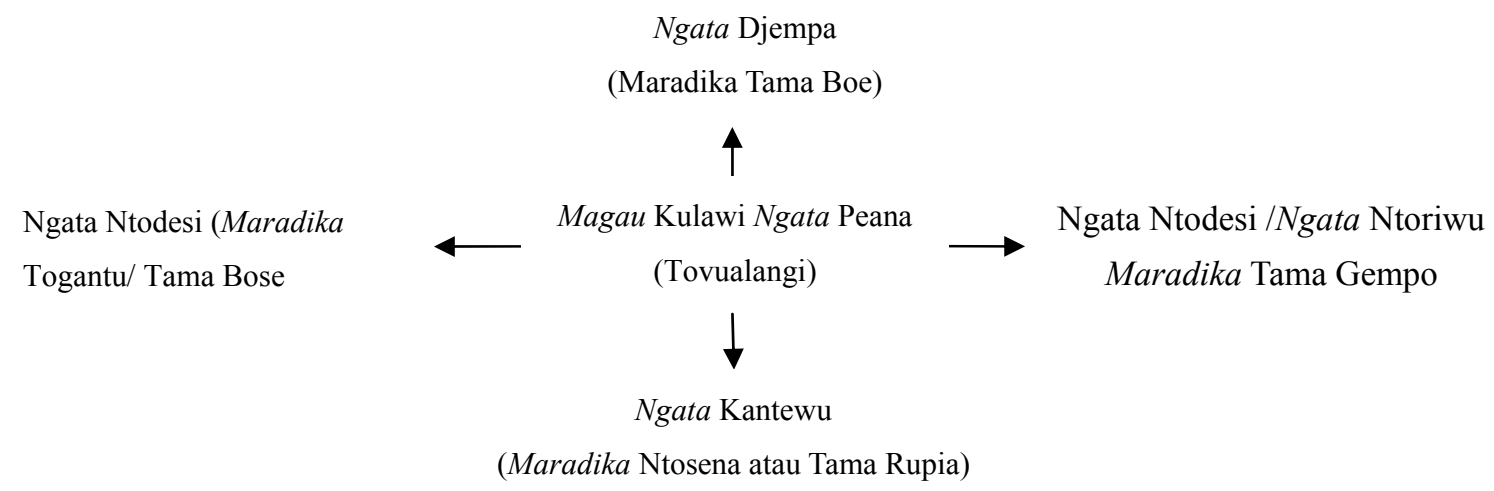

Source: Writer's Analysis 
Till this writing is published, based on an informant Yunus it is know that ngata Kantewu covers boyas like Boya Pangana, Poreka, Boya Wiliri and Boya Onu, each of boya lead by chieftain named Bawo and SL.Sango. Please note that in 1927, it was ruled Magau Matua in Kulawi that is Djiloy, assisted by Magau Malolo Djempa which was cenetered in Peana. When Kulawi governance was changed to Swapraja, the leader of swapraja was held by Maradika Djiloy and the District was lead by Jusuf Djiloy and the head of the Regency is Johanis Pongiri with the chieftain named Salumpana administered 32 villages, while in Peana ruled a District chief named Losso.

The conquest through korte verklaringen (short declaration), happened since 1904 can not overthrow the existing feudal system instead of making use of it.. Then they became a mediator between the leader and the people. The leader collected agricultural product of the people or farmers and some part were given to the colonizer as a tax or belasting. Even the Dutch gave wider area of authority and maintained the existing area. Meanwhile, the farmers were allowed to alive based on the traditional farming system. Farming system was also determined by the leader. In which the ownership of local land was handed over to the magaus, then magau approached maradika or nobleman in every ngata to collect taxes or belasting. In this case local regulation of Kulawi Kingdom was considered more tolerant compared with the Duct colonialism in the coastal regions of Central Sulawesi.

Colonial approach or ethic politics which is called as social approach by Yore Pamei became a main weapon to conquer Kulawi. As an agricultural area, agriculture which has been a major mainstay was revived trough the opening of several large plantations, like rattan, cacao, and coffee. Agriculture was revived during the new order through sharing system for small farmer. Technique of implementation was by organizing the owners of patron to produce certain agricultural commodity. All processes are determined in a agreement between patron and farmer as the client. The agreement diverted all the risk to the patron, but he take control for quality and pricing. Farmers in such system were separated from distribution, as the one in direct relation was patron (modal owner) and patron. This is the main cause for the strong relationship between the investors as the patron and sharecroppers as the client.

\subsubsection{Original Tradition Vonda Maple as a Type of Traditional Action}

Daeng Palisu explained that people involved in the harvest festival of traditional people are: (a) farm land owner (puempanga), (b) to tua dondi (bayasa) and topodondi which are the actor of social action who assigned to perform rego dance together with other members, and (c) punggawa ain who in charge to control community life in the past time. Magau is also indirectly involved as for the program will not run as smooth as usual without permission from magau. So they should ask permission to magau to run the program and invite magau to become respected guest in the peak program Vunja Mpae (VM) which is rego. Magau is the one to permit the process of $V M$ as a custom which become tradition. (Result of interview on August 252011 in Sidera village).

The nature of Vunja Mpae tradition means: a) thanksgiving for the abundant crops in the harvest, so it is believed that the ceremony is to keep social harmony both in the community and family as part of social system, b) if a scene the fall of a tree in the farm which then beset 
the paddy or embankment that means ada'ntana (adat tanah or commonly called as adat vunja), is not performed then it will cause the inhabitants of nature to get angry, and c) a belief of the existence of symbolic knowledge trusted by elder people, about the tradition of the elderly which is part of the convention. Symbolic knowledge meant is a ritual referred to an implicit understanding of useful tools which have deeper meaning in the form of concrete things such as food for the invisible things.

Traditional knowledge believed by elderly is a view referring to traditional action. In which actor of the farm owner and another actors as observer do not realize the purpose of what they did. When asked about the meaning of tradition for Hj. Dae Inta, a villager aged \pm 87 years, she responded the same with another informants, which they expressed in below sentences: "he has always been acting like this, he was just the same since now and then", it was a statement of Hasni Palimuri (in an interview on October 18, 2011 in a village named Bodi Karawana). Vunja Mpae tradition has been our tradition, if it is not performed then it seems inappropriate". The statement means that Vunja Mpae tradition is part of the people tradition which passed down through generations.

\subsubsection{Mauna Kalinin Vonda Maple Tradition (VMT) as a Traditional Action of Value Orientation}

Based on the opinion of Aswadin Randalemba, vunja mpae tradition is expected to be able to become one of village potential assets for cultural tourism as well as for a way to minimize poorness in which people of the village could sell snacks and clothes during the performance of vunja. Beside, another aspect for traditional action type shown in Vunja Mpae tradition is a type of action of value orientation. Value as shown in the tradition contains a value of local wisdom to build ethnic harmony and peace of Sigi Regency which at the same time to keep peaceful life among villages which is still vulnerable to conflict.

Local wisdom appeared in the performance of Vunja Mpae tradition is a fundamental principle to unify all values to keep social harmony in Sigi Regency. Local wisdom of VMT can be seen in the behavior of the front line of vunja mpae which are bayasa, bule and puempanga. They keep in believing the symbol of past time knowledge which can not be easily translatable by common people. It is believed as a special knowledge for bayasas and their descendants, so the knowledge about past time life will not necessarily socialized to their generation other than their descendants. Therefore the knowledge of symbols in VMT is only in the understanding of bayasa as the sole actor mainly the symbols in the traditional dance and rego song which is very difficult to translate by Kaili people who in listening to the song. Thus local wisdom of VMT can be a religious knowledge for basic principle of life for traditional people in behaving, both in the daily life and maintaining culture for future life. Table 1 shows TVM in the characteristics of tradition change. 
Table 1. Characteristics of tradition change

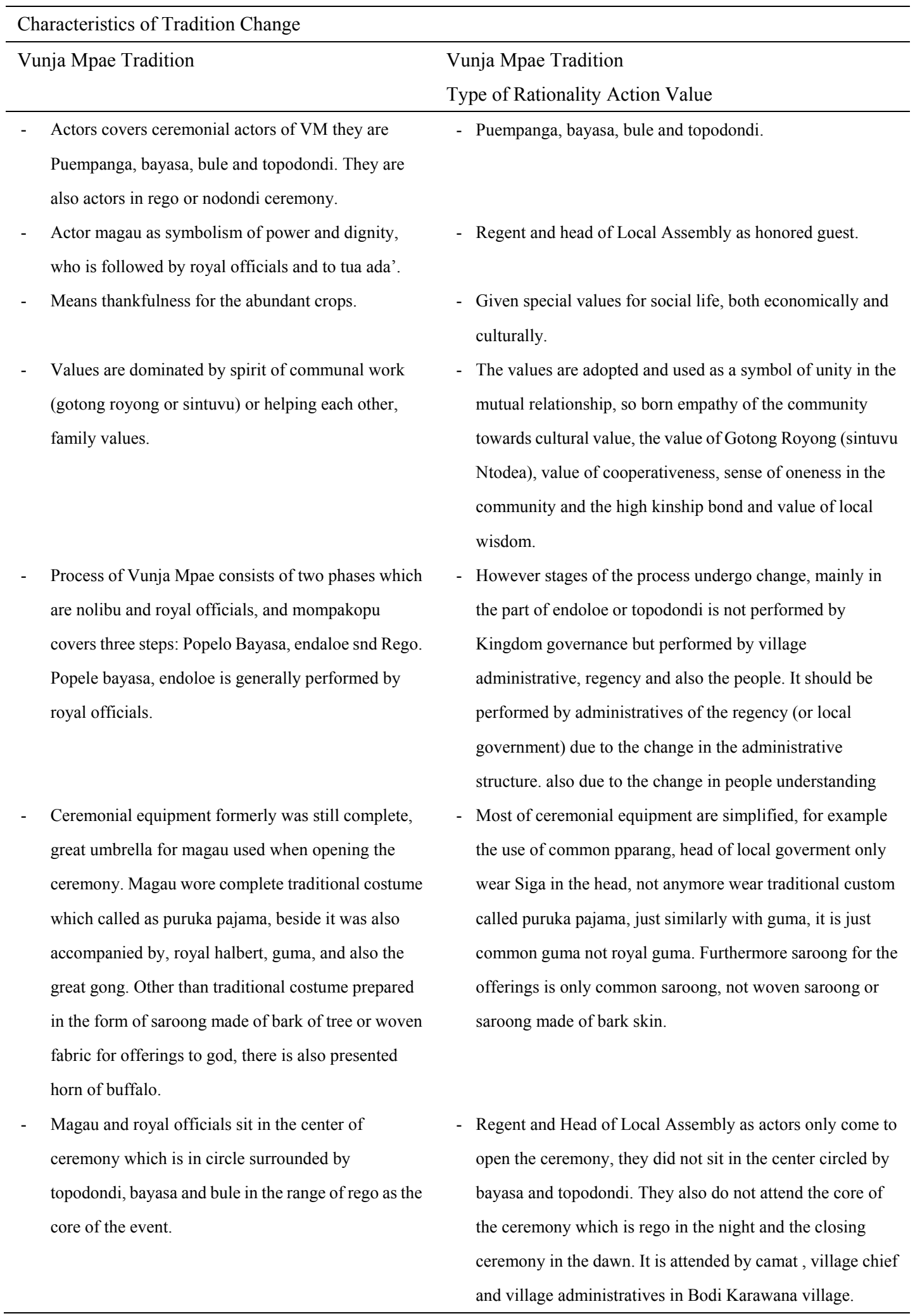

Source: Source Analysis, 2011. 
Characteristics of change in tradition based on Table 1 above can be seen in the behavior pattern of the actor acting as the leader, magau in vunja tradition presents to empower the throne, and also the charisma and dignity in front of his followers in traditional people, while the behavior of the chief of local government and the chairmen of the board attend the invitation as an actors is very rational because he meant to strengthen his political power.

\subsubsection{Beaten Tradition (Potitical Tradition) as Instrumental Rationality}

Political tradition evolves due to magau posses a full authority in his era and his dignity is increasing in the basis of his power as the leader of authority. This political tradition then produce integration as power weave among relatives and families in one unity which is clan.

VMT activity is build based on the tradition and local custom healthily and excitingly for the process of political learning for people as rational instrument in political career of certain clan group who want to remain exist as practitioner. Performing VMT people could understand what are the vision and mission of legislative and executive members in maintaining and developing past time heritage, and also they could determine how far their intellectual, emotional and spiritual capacity of the local elites, so that they could further consider their political choice more rational, traditional and cultural with symbol of values putting forward positive morality.

\subsection{Process of Villagers Transformation in Sigi Regency}

\subsubsection{Historical Transformation of Villagers in Sigi Regency}

It is said as a historical transformation as for the long period of time needed for the change. Villagers of Sigi Regency are in the topic, initiated with the narration of kingdom era (pra colonialism) to the Dutch colonialism.

The great influence arose due to historical transformation, up to now they still can feel the impact. Geographically, location of both are quite near each other, then it is reasonable enough if Dutch undergo integration process between both as for both of them are close each other in terms of geographical location. This condition was made use by Duct colony as the highest of the authority. The Dutch coming caused two kingdoms Sigi Kingdom and Dolo Kingdom become "Inlander" in the eyes of Dutch colony. After successfully taking over the Kingdom of Sigi, Dutch built facilities for regional needs of Kingdom of Sigi. Based on Hamdan Sanusi, during the Dutch governance, first step to do was to build force headquarters centered in Biromaru, Ampera building, and making use Biromaru market as ceremonial assembly for Dutch troops.

To historical transformation with Expansion of Sigi Regency indicated by the born of Communication Forum for Expansion of Sigi Regency (FKPKS) at 11.45 on August 14, 1999, with core administrator consisting of Habir Ponulele as chairman, asisited by vice chairman respectively Reynold Tarro and Daeng Tarusu Parampasi, Nurzain Djaelangkara as general secretary assisted by two vice secretaries which are Umar Latopada and Freddy Lody Djaru, with the overall structure, authority and administrative compositions of FKPKS designated in Biromaru on July 26, 2003. Followed by General Declaration (Deklarasi Umum) dated on 
November 251999.

\subsubsection{Clan Differentiation as Part of Transformational Process}

Clan is frequently referred as broad kinship or extended family. Clan based on the father line (patrilineal) is exist in the Kalili pople for the region of Sigi Regency, clan which has been long time influential is Lamakarate clan, Djaelangkara clan, and so on. Clan differentiation shown in their education as a creative instrument for the clan, in which education is an effort to make positive change to enhance individual dignity of community members to a higher decree and more progressive than before.

Clan differentiation due to wealthiness or legacy is indicated by the ownership right in the community such as car, house, buffalo, farm land, residential land, and also field, so those are the indicator of wealthiness among people of Sigi in general. Property of such ownership is largely possessed by Lamakarate clan, Djaelangkara clan and other powerful clans.

Ownership of land does not only belong to the clan, but also cover the ownership of land for community members. Community access to the land can be obtained from buying and hiring system, while people who do not have land can work as sharecropper for lands of the noblemen from Lamakarate clan, Djaelangkara clan, and also Lamasatu clan. Even from economically sustainable community members like Lapalege clan.

\subsubsection{Identity Characteristics as the Meaning of Transformational Process in Sigi}

In terms of social relationship, people of Sigi belong to a community with a high social diversity rate with specific social character. From the era of pre colonialism to colonialism era, farmer community has already know polarization system in the farm land ownership and sharecropper without farm land which in turn lead to the unclear land sharing of their ancestors. They are viewed as small farmer class which is homogeneously part of marginal social class due to the income difference; some of them are in class with enough income and some others are of insufficient income class. The two class of farmer community is getting hard in facing difficulty in terms of income as for agricultural products considered as unsuccessful commodity in the market; on the other side they are not capable of raising capital due to the prolonged historical process in their lives. This problem then raised dependency to the relatives with higher social and economical access in the village.

Difference in term of social characteristics arises due to the occupations which require different point of view and behavior in the community. What is clearly seen during the observation and interviews is the difference of attitude between a landlord and a sharecropper in the effort to increase their prosperity; the landlord orient his effort to collect wealthiness and get higher authority, farmer worker attempt to fulfill their substantial need so as sharecropper, so there will be difference in the effort of increasing their agricultural productivity.

\subsection{Consequence of Change in Tradition to Transformation in Sigi Regency}

Consequence of the change in tradition to transformation caused by 3 (three) components as follow: 
(1) Social cohesion in the clan internal is starting to fade; this is due to the appearance of other individual actors who have similar potential and chance due to the educational access that drive their social status to put in account.

(2) Social Mobility, This social mobility is horizontal social mobility, which is a transition of individual status or clan group to the equal level of social group. For example, the position of Lamakarate clan in colonial structure, they belong to a clan group with high social status when Indonesia reach its independence up to now, but it is only limited to people of Lamakarate clan who continually make higher social movement, keep on mobile and do not stop in process to only depend on the glorious inheritance, wealth inheritance, and inherited dignity of the original clan.

(3) Conflict of tradition between different generations, The conflict arises as for the older generation want to maintain tradition as personal symbol of self-sustainability with traditional way of thinking. Their way of thinking is indicated by their nature which remains simple with the desire of maintaining irrational tradition. Their work productivity is very low as for they keep on thinking traditionally, not willing to increase their agricultural productivity through more rational ways. This is contrary to the youth generation, youth has more rational way of thinking, they are willing to make change along with development, have future orientation, keep on learning efficiency and effectiveness, and also lay on the habit or tradition.

\section{Conclusion}

(1) Type of action in Traditional People covers, (a). type of traditional action with the orientation of actor of Venal Maple Tradition, (pumping, bays, blue and topodondi; and Vunja Mpae Tradition (magau or chief of the village); (b). type of rational action with value orientation, which are family and local wisdom value ; and (c). the third type, tradition as an instrument assumed as a tool to mobilize mass support in the level of local elite.

(2) The initial transformation of villagers is started from historical process, which then influence on the broader relationship among clan groups in the community in terms of socially, economically, and politically.

(3) Consequence of social change arise from the change of traditional community to trans formative community covers 1) inter-clan (fam) social cohesion, which include clan differentiation, high sentiment due to the same feeling of coming from the same clan, and 2) Inter-clan social mobility, and 3) conflict between elderly and young generation.

\section{References}

Abdullah,T., \& Sharoon, S. (1989). Tradisi dan Kebangkitan Islam di Asia Tenggara. Jakarta: LP3ES.

Bachtiar, W. (2006). Sosiologi Klasik. Bandung: Remaja Rosdakarya.

BPS. (2010). Kabupaten Sigi Dalam Angka. Palu: Cooperation between Regional Committee for Disaster Management (BPPD) of Sigi Regency and Central Bureau for Statistics (BPS) of Donggala Regency. 
Berry, D. (2003). Pokok-Pokok Pikiran Dalam Sosiologi (4th ed.). Jakarta: Raja Grafindo Persada.

Bubandt, N. (2004). Menuju Sebuah Politik Tradisi Yang Baru? Jurnal Antropologi Indonesia. No.74.

Burke, P. (2001). Sejarah dan Teori Sosial. Jakarta: Yayasan Obor Indonesia.

Department of Education and Culture. (1996/1997). Sejarah Daerah Sulawesi Tengah. Jakarta: General directorate of Culture.

Eke, S. (n.d.). Ekonomi Politik Pembaharuan Desa. Retrieved from http://www.ireyogya.org/sutoro/ekonomi_politik_pembaharuan_desa.pdf

Flower, J. (n.d.). Aiken South California: A Case Study of Community Transformation, California.

Frits, K. A. (n.d.). Pemberdayaan Masyarakat Lokal (Nelayan) Menuju pada Transformasi masyarakat. $\quad$ Retrieved March 11, 2011, from http://jurnal.pdii.go.id/admin/jurnal/7209499510.pdf

Garcia, J. (2004). Ecuador Peasant. Retrieved February 25, 2011, from http://www.photius.com/ecuador/society/ecuador_society_peasant.html

Garna, J. K. (1993). Tradisi, Tranformasi, Modernisasi dan Tantangan Masa Depan Di Nusantara. Bandung: Master Program - University of Padjajaran.

Gibson, T. (2009). Kekuasaan: Raja, Syeikh, dan Ambtenaar. Makassar: Ininnawa.

Hasan, N., \& Wilman, D. L. (2006). Sejarah Tojo Una-Una. Yogyakarta: Ombak.

Husken, F. (1998). Masyarakat Desa Dalam Perubahan Zaman: Sejarah Diferensiasi Sosial di Jawa 1830-1980), Jakarta: PT. Gramedia Widiasarana Indonesia.

Isyanti. (2007). Tradisi Merti Bumi Suatu Refleksi Masyarakat Agraris (pp. 131-135). Jantra.

Johnson, P. D. (1986). Teori Sosiologi Klasik dan Modern. Jakarta: Gramedia.

Jonathan, H. T. (1990). The Structure of Sociological Theory. Belmont, California: A Division of Wadsworth, Inc.

Kodesh, N. (n.d.). Reimagining Tradition: The Politics of Succession in Colonial Buganda. Retrieved $\quad$ February 25, 2011, from http://www.north.western.edu/african-studies/does/working-papers/wpgkodesh.pdf

Kruyt, A. C. (1938). De West-Toradjas Op Midden-Celebes (Deel I), Uit Gave van de N.V. Noord-Hollandsche, Uit Gevers-Maatschappij, Amsterdam.

Kurasawa, A. (1993). Mobilisasi dan Kontrol. Studi Tentang Perubahan Sosial di Pedesaan Jawa 1942-1945. Jakarta: Gresindo.

Lammel, A., \& Ilona, N. (1992). Creating Myths in Kalevala and in Hungarian Oral Tradition. 
Nordic Journal of African Studies. Retrieved February 24, 2011, from http://www.njas.helsinki.fi/pdf-files/vol1 num2/lammel.pdf

Lerner, D. (1983). Memudarnya Masyarakat Tradisional. Yogyakarta: Gajah Mada University Press.

Mahid, S., Haliadi, S., \& Syafrullah, A. (2002). Sejarah Sosial Sulawesi Tengah, Yokyakarta: Published in the name of Cooperation between Culture and Tourism Department Central Sulawesi Province and Center for Historical Writing (Pusat Penulisan Sejarah) Writing Institute University of Tadulako and Pilar Media.

Nari, M. (2009). Dinamika Pemekaran Daerah dan Perubahan Struktur Sosial Masyarakat (Studi Daerah dan Perubahan Struktur Sosial Masyarakat (Studi Kasus Pembentukan Daerah Kabupaten Toraja Utara Provinsi Sulawesi Selatan). Dissertation is not published. Makassar: Master Program State University of Makassar.

Narwoko, \& Bagong, S. (2007). Sosiologi Teks Pengantar dan Terapan. Jakarta: Kencana.

Nurulaen, Y. (2004). Pendidikan Ketrampilan bagi Masyarakat Pedesaan (Suatu alternatif Untuk Mencegah Urbanisasi). Jurnal Pendidikan dan Kebudayaan, 48, 427-445.

Rachmad, K. D. S. (2008). Sosiologi Lingkungan. Jakarta: Rajagrafindo Persada.

Redfield, R. (1963). The Little Community, Peasant Society and Culture. Toronto: The University of Chicago Press.

Septiarti, S. W. (1994). Transformasi Sosial Masyarakat Dalam Perspektif Strukturalisme Fungsionalisme Suatu Tinjauan Sosiologis. Cakrawala Pendidikan, 3, 127-138.

Sumintarsih. (2007). Dewi Sri Dalam Tradisi Jawa. Jantra. No. 3. pp. 136-144.

Sumarjan, S. (1982). Perubahan Sosial di Yokyakarta. Yogyakarta: Gadjah Mada University Press.

Sztompka, P. (2008). Sosiologi Perubahan Sosial. Jakarta: Prenada.

Taryana, D. (1999). Perencanaan dan Program Pembangunan Di Pedesaan. Pendidikan Geografi. No. 2. pp. 68-75.

Ufford, F. H., \& Dirk, K. (1989). Tendensi dan Tradisi Dalam Sosiologi Pembangunan. Jakarta: Gramedia.

\section{Copyright Disclaimer}

Copyright reserved by the author(s).

This article is an open-access article distributed under the terms and conditions of the Creative Commons Attribution license (http://creativecommons.org/licenses/by/3.0/). 